Journal of Teacher Education for Sustainability, vol. 19, no. 1, pp. 82-105, 2017

\title{
Evaluation of Sustainable Development in Rural Territories in Latgale Region (Latvia) by Using the Conception of Smart Specialization
}

\author{
Viktorija Šipilova and Inta Ostrovska \\ The Institute of Humanities and Social Sciences, Daugavpils University, Latvia \\ Elita Jermolajeva \\ Latvian Academy of Agricultural and Forestry Sciences, Latvia \\ Ludmila Aleksejeva \\ The Department of Economics and Sociology, Daugavpils University, Latvia \\ Dmitrijs Oḷehnovičs \\ The Department of History, Daugavpils University, Latvia
}

\begin{abstract}
One of the approaches to achieve sustainable development is based on smart specialization. Rural areas are of particular importance in ensuring sustainable development, the smart development of which largely determines the balanced sustainable development of a state as a whole. The present study reflects the quantitative and the qualitative assessment of sustainable development in the region of Latgale (Latvia) on the level of 19 districts; the assessment has been carried out on the basis of the concept of smart specialization. The assessment has been performed within the framework of the project 5.2 of the National Research Programme EKOSOC-LV. The quantitative assessment is based on scientific and practical experience taking into consideration the distinguishing features of the development of Latvian regions and districts, and it has resulted in the establishment of an integrated index (Smart Development Index), which comprises four dimensions Resources, Population, Economy, and Management. The qualitative assessment is based on the views concerning the cornerstones of smart specialization and the factors influencing it expressed by experts from the state administration, business and scientific environment. Expert opinions have been collected by using Analytic Hierarchy Process (AHP) method. The results of the research might facilitate the understanding of the support measures of smart specialization and the opportunities for sustainable development in rural areas, taking into account the level of the regional socio-economic development and the rate of development, as well as regional differences on the level of districts. The example of Latgale has shown that a small number of people and a low rate of development in most of the region districts simultaneously create both the acute need for and a great challenge in the sphere of sustainable development. By contrast, as a result of both the
\end{abstract}


quantitative and the qualitative assessment the population has been recognised to be the main driving force of the development of rural areas in Latgale region.

Keywords: sustainable development, smart specialization, rural areas, Latgale region (Latvia).

\section{Introduction}

Within the European Union's strategy for sustainable development, sustainable development is considered the development that meets the needs of present generations without jeopardising the ability of future generations to meet their own needs. It is the development that safeguards the earth's capacity to support life in all its diversity. It is based on the principles of democracy, gender equality, solidarity, the rule of law and respect for fundamental rights, including freedom and equal opportunities for all. It aims at the continuous improvement of the quality of life and well-being of present and future generations (Eiropas Savienības Padome, 2006).

The European Commission (2012) indicates that smart specialization is essential for sustainable development. The studies on the promotion of sustainable development on the basis of the concept of specialization emphasise interdisciplinarity, for instance, in bio-economics regions, which search for new ways of strategic development, might strive for sustainable added value production by supplementing, improving and transforming their activities in traditional spheres (such as forestry, agriculture, fisheries). Both scientists and practitioners emphasise that the analysis in the sphere of a region's potential in sustainable development should be started by evaluating environmental, economic, social and managerial aspects (European Commission, 2012; e.g., Kirk et al., 2010).

The shift to modern regional development paradigm has facilitated the awareness of the importance of each region's potential and endogenous factors (e.g., Vanthillo, Verhetsel, 2012). However, at the same time the issue about the pronouncedly different possibilities of various territories to safeguard sustainable development is becoming acute. Solving local problems by using local uniqueness and comparative advantages, probably, is the right approach, and it is supported in both scientific and practical spheres. Such an approach requires the implementation of the concept of smart specialization (e.g., Naldi et al., 2015; Koumparou, 2013). In fact, it means to develop and put into practice the strategies of smart growth and development, which are based on the assessment of a region's potential and capacity, and prioritisation. It is a particularly great challenge for rural areas, which are often characterised by a small number of inhabitants, low income, low level of education and a considerable distance from "knowledge" centres (e.g., Steiner, Mossbock, 2014) and necessity to solve issues on effective service delivery (e.g., Arcelus et al. 2015). Another challenge is related to the limited experience in assessing sustainable development in the economic context, and in rural areas, since the assessment is in most cases focused on environmental issues (e.g., Krueger, 2010) and cities (e.g., Sinkiene et al., 2014).

The paper offers the methodological solution to the assessment of sustainable development in the economic context in rural areas by using the concept of smart specialization that has been developed within the framework of the National Research Programme EKOSOC-LV. The authors have researched Latgale region and its 19 districts in Latvia by carrying out their quantitative and qualitative assessment. The rest of the paper is organised as follows: the second section proposes the theoretical and methodological 
concept of sustainable development; the third section characterises the existing development trends in Latgale region; it presents new knowledge about the distinguishing features of the development of Latgale region, i.e. the quantitative assessment of sustainability by using the concept of smart specialization, as well as the qualitative assessment of sustainability by using the concept of smart specialization and providing the triple-helix representatives' (experts') viewpoints. The fourth section of the paper draws conclusions.

\section{Theoretical and Methodological Concept of Sustainable Development}

\section{Sustainable development in the research perspective}

The notion of sustainability has quite recently been linked to regional development owing to the understanding that sustainable development should balance environmental, social and economic needs. However, the emphasis in scientific and practical works is put on environmental issues, the others being somehow neglected (for instance, Krueger, 2010). Consequently, the concept that is intended to merge sustainability with economic development is relatively new and little explored. For example, the Scopus database contains only a limited number of publications that focus directly on sustainable economic development. The publications that investigate sustainable economic development mainly reflect smart specialization approaches by means of implementing the policies of smart growth and smart development, thus "building a bridge" to the development of knowledge economy. In this respect, it is important to understand that knowledge creation, diffusion and absorption require the existence of the so-called innovative ecosystem, in the framework of which knowledge would promote the flourishing of innovative entrepreneurship (e.g., Romano et al., 2013).

The term "smart", notwithstanding its popularity in the concepts of theory development, has not been precisely defined and its interpretations may differ within different scientific disciplines (Sinkiene et al., 2014). In economic literature, smart development is related to the fundamentals of sustainable development (Naldi et al., 2015); and in the USA, smart development is understood as sustainable development (e.g., Krueger, 2010).

As indicated by Koumparou (2013), growth and development in the European Union are related to the solution of local problems by emphasising the uniqueness, comparative advantages, and available resources of each territory. Assurance of such an approach is possible by using the strategy of smart development (Koumparou, 2013). One of the possibilities to achieve sustainability in economic development envisages active use of natural resources and social capital, thus promoting effective use of resources through collective actions of the society that, to a certain extent, requires the coordination of activities (Koumparou, 2013), i.e., the implementation of certain policies aimed at achieving the balance between economy, social equality and environment (e.g., Krueger, 2010). To some extent, the necessity of the development policies is to be linked to sometimes weak market response to manifestations of sustainability (e.g., Krueger, 2010).

In their study, Naldi et al. (2015) confirm that the goal stated in the strategy "Europe 2020 ", i.e., to promote smart, sustainable and inclusive economic development is achievable if diverse policies of smart growth and smart development are developed. However, there is also a more critical point of view with regard to the development of smart growth and development strategies, which emphasises that the development process itself does not oblige the strategy execution (e.g., Reimeris, 2016). Reimeris (2016) also 
recognises that smart development strategies (e.g., RIS3) provide a mechanism for the promotion of changes and the development of important vectors of future policies. Additionally, well-elaborated regional development policies that clearly identify priorities, evaluate available resources and possible obstacles are important for realising regional potential during the implementation of set aims (e.g., Šipilova, 2014).

According to the OECD (2013), the concept of smart specialization envisages policy intelligence, for instance, when determining comparative advantages, priorities in specialization and combining the potentials of all the parties involved. The practice shows that the policy of introduction and implementation of smart specialization is dependent on the type and the potential of a region (see, for instance, the study about Northern Europe by Lindqvist et al. (2013)). However, Lindqvist et al. (2013) indicate that there are also common factors of "success", for instance, the "critical mass" performance analysis and interdisciplinary, cross-sectoral cooperation and partnership between regions at different levels. Research on the success of economically less developed regions in the sphere of smart specialization and innovative activity is related to the abilities of regional management and the availability of financing from the European Union structural funds (e.g., Muscio et al., 2013). Muscio et al. (2013) also note that the relatively modest performance of economically less developed regions (e.g., East European countries) in the sphere of smart specialization is connected with a region's particularly pronounced weak management capabilities. Furthermore, Muscio et al. (2013) emphasise that these weak management abilities manifest themselves not at the level of prioritisation, but rather at the level of programme implementation.

More and more experts acknowledge that sustainability should be viewed locally, i.e., at the level of municipalities, urban or metropolitan regional level (e.g., Shen et al., 2011; Sustainable Cities, Canadian International Development Agency, 2012). At the same time, the complexity of the implementation of the stated goals is emphasised particularly in pronouncedly different rural areas (Naldi et al., 2015). 2/3 of the European population lives in cities (European Union. General Directorate for Regional Policy, 2011); and it determines the experience restriction in relation to the introduction of smartness in rural areas. For example, studies on sustainable development mostly focus on cities (e.g., Sinkiene et al., 2014). On the other hand, the prevalence of ecological questions in the concept of sustainability (e.g., Krueger, 2010) promotes the interest into one sector of economic activity in rural areas, i.e., the agricultural sector (e.g., Reidsma et al., 2015; Sandu, 2014 etc.). However, it should be noted that the concept of sustainable development in rural areas is to be considered in a wider context, too.

There is no single method that would be appropriate in all the cases when it is necessary to develop a strategy for sustainable development. Each area has its own unique needs. However, there are a number of common aspects that should be taken into consideration when drawing up the strategy. It is essential to note that most approaches offer a holistic view that includes environment, society, economy and management and implies the use of diverse measurable indicators.

\section{The methodological solution}

The process of assurance of sustainable regional development in Latvia is linked to the potential of the regions (Pārresoru koordinācijas centres, 2012) and in this process the polycentric development is of special significance (Melbarde, Ore, 2016). At the 
moment, the rural areas that notify themselves especially vividly are the ones where there are tendencies incompatible with the fundamentals of sustainability observed. These trends are the decrease in the number of population, aging population, decline in business activity, etc. (e.g., Latgales plānošanas regions, 2010a, 2010b). It should be noted that, according to the typology of rural areas adopted in research practice, rural areas are generally characterised by low income, low level of education, low economic activity and considerable distance from the so-called centres of knowledge (e.g., Steiner, Mossbock, 2014).

The goal of the National Research Programme EKOSOC-LV is to develop an instrument that would enable researchers to offer scientifically grounded propositions for the assurance of balanced and sustainable rural development (Latvijas Zinātnuu Akadēmija, 2014). One of the greatest challenges is the methodological solution that would enable an objective assessment of the current situation and the development potential and priority directions, taking into account the concept of smart specialization in ensuring sustainable development.

Methodological challenges related to the implementation of smart specialization are topical also in Lithuania, the neighbouring country of Latvia (e.g., Poliakaite et al., 2015). As concluded by Poliakaite et al. (2015), the development and implementation of the concept of smart specialization at the local level require active process of clarification and discussion involving all interested parties. Moreover, these activities should be understood as an investment, rather than a burden. In addition to this conclusion, the Lithuanian colleagues agree that a holistic approach and the promotion of innovation in any field of activity form the path to successful implementation of smart specialization strategy (Poliakaite et al., 2015). Similar conclusions have been made by the authors of the article (Ostrovska et al., 2016), when analysing the characteristic features of the contemporary regional development paradigms as described in research literature. Ostrovska et al. (2016) have concluded that the cooperation among the parties involved in the process of regional development is an essential prerequisite for smart development, while the holistic approach, which combines environment, society, economy and management to meet the unique regional needs, is the basis for ensuring sustainable development.

Within the framework of the National Research Programme EKOSOC-LV being at the 3rd stage of its implementation, the researchers have at their disposal the quantitative and qualitative indicators that allow determining the level and the characteristics of smart development, as well as making assumptions on the development of the desired situation in Latvian rural areas. It is noteworthy that in research literature it is hardly possible to find a single common approach and specific data selection for assessing regional development at the global level. This is also noted in the research carried out by Huggins et al. (2014) about the world's more developed (and productive) regions, including into the study 54 regions of North America, 41 from Europe, 22 from Asia and Oceania. Within their study, Huggins et al. (2014) performed the analysis of the evolution and competiveness of regional economy taking into account the latest research developments in the spheres of regional competitiveness, regions of knowledge and knowledge-based development.

Within the present study, the authors have carried out three successive steps in order to evaluate sustainable development on the basis of the concept of smart specialization: 1) characterisation of the development of rural areas by offering a refreshed view on the types of rural areas; 2 ) the quantitative description of the development by using 
the concept of smart specialization; 3) the qualitative characterisation of the development by involving state, business and scientific experts in the evaluation process. Such an approach allows for the understanding of the distinguishing features of the current development from the point of view of sustainability by answering two questions What is the situation? and What should it be?; and comparing the answers.

\section{Evaluation of sustainable development by using the conception of smart} specialization

\begin{tabular}{|c|c|c|c|c|}
\hline $\begin{array}{c}\text { Quantitative } \\
\text { assessment } \\
\text { Typology of rural areas } \\
\text { developmenting on the rate of } \\
\text { development }\end{array}$ & $\begin{array}{c}\text { Qualitative } \\
\text { assessment } \\
\text { art Development Index that } \\
\text { combines 4 dimensions } \\
\text { (Resources, Population, } \\
\text { Economy, Management) }\end{array}$ & $\begin{array}{c}\text { Representatives of the tripple- } \\
\text { helix model } \\
\text { (state, entrepreneurship, } \\
\text { research) }\end{array}$ \\
survey by using the AHP method
\end{tabular}

Figure 1. The methodological solution for the assessment of sustainable development in rural areas

Source: EKOSOC-LV.

The quantitative assessment. Before carrying out an assessment of sustainable development, it is essential to understand the typology of rural areas and its features. In the development of the typology of rural areas, the EDORA Cube principles were partially used according to Copus and Noguera (2010). Rural areas were divided according to their rate and level of development, as well as the number of population, which allowed revising the stereotypes concerning the rural areas. The development of the typology was based on the data on the dynamics of economically active statistical units of the market sector and sole proprietorships (the rate of development) (RDIM, 2015) and the index of territorial development (level of development) (SRDA, 2010, 2011, 2012). Such a division of territories provided the understanding of the current capacity of rural areas. The answer to the question "To what extent is this developmental capacity echoed in smart rural development?" was sought for by developing the Smart Development Index.

By its nature, the Smart Development Index as a quantitative indicator of smart development, which shows the level of smart development of an area, is an integrated index that includes four dimensions - Resources, Population, Economy and Management, thus respecting the characteristic features of the concept of smart specialization. The choice to develop the integrated indicator has been based on the conclusions found in research literature. In research literature it is emphasised that to carry out an effective assessment of the current situation it is necessary to consider not only the selection of definite indicators, but also the integrated index that allows assessing common achievements in a particular field (e.g., Marsal-Llacuna et al., 2015) or evaluating the uniqueness of the area (e.g., Gedminaite-Raudone, 2014).

The Smart Development Index includes the statistical data on: Resources - available resources, efficiency of their use, infrastructure; Population - the level of education, business activity, the desire to be creative and to learn; Economy - innovative companies, 
level of population's involvement in entrepreneurial activity; Management - the ability to attract funding, e-management, population's activity.

It should be noted that during the development of the index, the importance of each dimension in the index was also considered - Resources 0.19, Population 0.26, Economy 0.44, and Management 0.11. The calculated values testify to the fact that Economy and Population have the largest weight in the process of smart development, while the weight of Resources and Management is considerably smaller. The Smart Development Index adopts both positive and negative values, which are respectively indicative of the level and the quality of smart development of an area.

The qualitative assessment. Finally, in the course of the study, the triple-helix model was actualised. This model is essential for the assurance of sustainable development and shows the preferred model of cooperation of the participants involved in the development. The project participants attracted to the research process the experts - representatives of the state, entrepreneurship and research - who were interviewed about the driving forces of smart development (Resources, Population, Economy, Management), as well as about the spheres that most affect the level of smart development (activities of population, municipalities, state, and the European Union activities). The method used to carry out the experts' survey was the Analytic Hierarchy Process (AHP). The experts' answers provided the knowledge that allowed comparing the current situation with the desired one, thus becoming aware of both strengths and weaknesses of smart development.

The paper presents the assessment of sustainable development carried out by using the concept of smart specialization in rural areas in Latgale region (19 districts) in Latvia in the period of 2009-2014. The assessment is based on the awareness that the paradigm of the contemporary regional development requires observing a multidimensional, interdisciplinary, involving and uniting activity aimed at the use of a region's potential (Ostrovska et al., 2016).

\section{Research Results}

\section{The Description of the Existing Development Trends in Latgale Region}

The biggest challenge in Latgale region is related to the loss of human capital and the sluggish development trends in entrepreneurship (e.g., Latgales plānošanas reǵions, $2010 \mathrm{a}, 2010 \mathrm{~b})$. The programme and the strategy of the region's development (e.g., Latgales plānošanas reǵions, 2010a, 2010b) envisage a set of measures aimed at mitigating the negative trends; these measures are based on raising efficiency of the use of local resources, on activating the cooperation among the parties involved in development, strengthening of the business sector (e.g., Latgales plānošanas reǵions, 2010a, 2010b). Special attention in Latgale region is devoted to education contribution to sustainable development that increases the value of human capital in the region. For example, successful practice at the regional university (Daugavpils University, Latgale region, Latvia) demonstrates the introduction of the concept of sustainability in the educational process (e.g., Salīte et al., 2016; Salite et al., 2015; Salite, 2015). This, in turn, can be recognised as a significant factor stimulating sustainable development in the region, because as Iliško et al. (2015) indicate, students' awareness of future changes contributes to sustainability in development. 
From an economic perspective, a significant contribution to the development of Latgale region is ensured by the relatively successful operation of the medium-high technology sector of manufacturing, and the use of rich natural resources (e.g., Latgales plānošanas reǵions, 2010a, 2010b). However, it should be noted that the potential of the rich natural resources of Latgale region, due to a low economic activity, is mostly used with a low added value (e.g., Latgales plānošanas reǵions, 2010a, 2010b), but bright specialization in the medium-high technology sector of manufacturing does not provide the desired contribution to regional development because of low growth of labour productivity compared to other sectors (Šipilova, 2015). At the same time, the issue of low growth of labour productivity relates not only to Latgale region and is among the main reasons for worsened external competitiveness of economy in Latvia (e.g., Baldi, Šipilova, 2014).

The vision of the region's development is directed towards the promotion of sustainable development and is grounded on the concept of smart specialization because it emphasises the necessity of the holistic approach, the enhancement of cooperation among triple-helix participants, as well as the introduction of green and innovative economy (e.g., see Ostrovska et al., 2016 for the literature review). It is logical that all districts of the region should involve in order to achieve the goals set, thus implementing the requirements of polycentric development (e.g., Pārresoru koordinācijas centrs, 2012; Melbarde, Ore, 2016) and ensuring the implementation of smart specialization by involving the potential of each region in the promotion of sustainable development.

Thorough understanding of the on-going development at the level of districts is provided by a fresh view on the typology of rural areas, i.e., whether the dynamics of certain statistics available fully reflect the current situation. Combining the data on the development rate and the development level promotes this understanding and can offer deeper knowledge necessary for the implementation of strategic goals at the level of districts.

Table 1

Groups of the Development Rate and the Development Level in Latgale Region

\begin{tabular}{|c|c|c|c|}
\hline (I) LOW RATE & $\begin{array}{l}\text { (II) RATE BELOW } \\
\text { AVERAGE }\end{array}$ & $\begin{array}{l}\text { (III) RATE ABOVE } \\
\text { AVERAGE }\end{array}$ & (IV) HIGH RATE \\
\hline \multicolumn{4}{|c|}{ High level } \\
\hline Districts: & Districts: & Districts: & Districts: \\
\hline Krāslava -1.035 & Balvi -0.821 & Daugavpils -0.877 & Vārkava -1.017 \\
\hline Līvāni -0.625 & Rugāji -1.023 & & \\
\hline Preili -0.810 & Ilūkste -0.964 & & \\
\hline Ludza -0.951 & & & \\
\hline \multicolumn{4}{|c|}{ Low level } \\
\hline Districts: & Districts: & Districts: & Districts: \\
\hline Baltinava -1.308 & Dagda -1.268 & Cibla -1.352 & - \\
\hline Rēzekne -1.141 & Kārsava -1.424 & Zilupe -1.487 & \\
\hline Riebinin -1.121 & Aglona -1.258 & & \\
\hline Vilaka -1.188 & & & \\
\hline Viḷāni -1.530 & & & \\
\hline
\end{tabular}

Source: EKOSOC-LV data, calculations made using data of the SRDA, 2010, 2011, 2012; RDIM, 2015. 
The calculations on the development level and rate in 19 districts of Latgale region reveal an alarming trend - a low or below average development rate is being observed in 15 of 19 districts of Latgale, and 8 out of 15 districts are characterised by a low level of development. This means that the rural areas where, according to the calculations, the socio-economic indicators fall behind the indicators of the region and the state (districts of Baltinava, Rēzekne, Riebiṇi, Viḷaka, Viḷāni, Dagda, Kārsava and Aglona), in practice show rather inexpressive movement towards the improvement of the situation. Only Cibla and Zilupe districts, which are characterised by a low level of development in the period considered, have shown the growth rates above average. On the other hand, the data on nine districts of Latgale, which have reached a relatively high level of development, also indicate certain stagnation. Thus, only Daugavpils and Vārkava districts have managed to achieve the development rate that is above average or high. The other seven districts (Krāslava, Livvani, Preiļi, Ludza, Balvi, Rugāji, and Ilūkste) feature the development rate that is low or below average.

The analysis performed allows identifying the following trends: 1) the districts with a relatively high level of development show stagnation; 2) some of the less developed districts are able to increase the pace of development. On the one hand, the identified trends may indicate certain "confusion" of the districts about the further realisation of their potential due to the lack of sufficiently strong impulses. On the other hand, it is positive that the relatively less developed regions accelerate their development.

All in all, the rural areas of Latgale region exhibit a striking dominance of slow development. According to the paradigm of contemporary regional development, one of the most essential driving forces of development is a human being; therefore, it is essential to understand the "stagnating" and "fast growing" rural population.

Table 2

Groups of the Development Rate and the Number of People in Latgale Region

\begin{tabular}{|c|c|c|c|}
\hline (I) LOW RATE & $\begin{array}{l}\text { (II) RATE BELOW } \\
\text { AVERAGE }\end{array}$ & $\begin{array}{l}\text { (III) RATE ABOVE } \\
\text { AVERAGE }\end{array}$ & (IV) HIGH RATE \\
\hline \multicolumn{4}{|c|}{ POPULATION (thousand) } \\
\hline $1112-7686$ & $7686-14256$ & $14256-20826$ & $20826-27396$ \\
\hline Districts: & Districts: & Districts: & Districts: \\
\hline Aglona & Balvi & Krāslava & Daugavpils \\
\hline Baltinava & Dagda & & Rēzekne \\
\hline Cibla & Ludza & & \\
\hline Rugāji & Līvāni & & \\
\hline Vārkava & Preil̨i & & \\
\hline \multicolumn{4}{|l|}{ Zilupe } \\
\hline \multicolumn{4}{|l|}{ Riebini } \\
\hline \multicolumn{4}{|l|}{ Viļaka } \\
\hline \multicolumn{4}{|l|}{ Kārsava } \\
\hline \multicolumn{4}{|l|}{ Ilūkste } \\
\hline Viḷāni & & & \\
\hline
\end{tabular}

Source: EKOSOC-LV data; RDIM, 2015.

The division of Latgale's districts into groups depending on the pace of development and the number of population displays that relatively highly populated areas are capable of achieving the development rate that is high or above average. In contrast, little 
populated areas show the tendency to stagnation. Have highly populated rural areas previously been able to achieve a high level of development? By combining the data presented in Tables 1 and 2, it may be concluded that those are highly populated areas that are capable of achieving high level of development; this has been observed in two of the three highly populated districts (districts of Krāslava and Daugavpils).

Given that in 16 of 19 districts of Latgale the number of people is rather small and their development rate is slow, the assurance of sustainable development becomes not only an acute necessity but also a challenge. Consequently, one of the main tasks is to understand the characteristic features of smart specialization and its potential driving forces in Latgale region and its districts.

The New Knowledge Concerning Distinguishing Features of the Development of Latgale Region

The Quantitative Assessment of Smart Development: Evaluation of Sustainability on the Basis of the Concept of Smart Specialization

The improvement of a region's welfare in the framework of a new paradigm of regional development should be linked to strengthening the competitiveness of territories by making use of their potential (e.g., ESPON, University Rovira i Virgil, 2012), i.e., resources, social capital, technologies, efficient management, and institutional capacity. Placing emphasis on the appropriate aspects of regional development is a major challenge for every region. The development of an integrated indicator (Smart Development Index), which includes all the dimensions necessary for regional development (Resources, Population, Economy and Management) allows identifying the developmental trends in Latgale anew.

Table 3

Smart Development Index in Latvian Regions - Descriptive Statistics

\begin{tabular}{llllc}
\hline Regions & \multicolumn{1}{c}{ Max } & \multicolumn{1}{c}{ Min } & Average & Median \\
\hline $\begin{array}{l}\text { Latgale } \\
(\mathrm{n}=19)\end{array}$ & $\begin{array}{l}7.386 \\
\text { Ilükste district }\end{array}$ & $\begin{array}{l}-5.113 \\
\text { Zilupe district }\end{array}$ & 1.074 & 0.43 \\
\hline $\begin{array}{l}\text { Kurzeme } \\
(\mathrm{n}=18)\end{array}$ & $\begin{array}{l}10.554 \\
\text { Alsunga district }\end{array}$ & $\begin{array}{l}-10.008 \\
\text { Skrunda district }\end{array}$ & 1.802 & \multirow{2}{*}{3.07} \\
\hline $\begin{array}{l}\text { Pierīga } \\
(\mathrm{n}=28)\end{array}$ & $\begin{array}{l}12.774 \\
\text { Carnikava district }\end{array}$ & $\begin{array}{l}-6.88 \\
\text { Mālpils district }\end{array}$ & 2.376 & \multirow{2}{*}{1.51} \\
\hline $\begin{array}{l}\text { Vidzeme } \\
(\mathrm{n}=25)\end{array}$ & $\begin{array}{l}\text { 16.642 } \\
\text { Césis district }\end{array}$ & $\begin{array}{l}-3.617 \\
\text { Rējiena district }\end{array}$ & 4.380 & \multirow{2}{*}{4.03} \\
\hline $\begin{array}{l}\text { Zemgale } \\
(\mathrm{n}=20)\end{array}$ & $\begin{array}{l}\text { 18.694 } \\
\text { Ozolnieki district }\end{array}$ & $\begin{array}{l}-7.89 \\
\text { Nereta district }\end{array}$ & 1.907 & 1.06 \\
\hline
\end{tabular}

Note: $\mathrm{n}$ - number of districts in region.

Source: EKOSOC-LV data.

The average values of the Smart Development Index indicate that the level of smart development in Latgale region is comparable to the performance of other regions. For instance, both Kurzeme and Zemgale regions demonstrate the average values of the Smart Development Index that are close to those of Latgale region.

In addition, the lowest index value $(-10.008)$ has been encountered in Skrunda district of Kurzeme region, rather than in Latgale region, where the lowest index value 
is -5.113 in Zilupe district, which is indicative of twice higher level of smart development in the district.

The maximum values of the Smart Development Index also show that such clearly unfavourable development in Latgale region is not observed. The maximum value of the index 7.386 attained in Ilükste district of Latgale region is not far from the maximum value of the index reached in Kurzeme region, which is 10.554. In addition, it may be concluded that smart development in Latgale region proceeds smoother than in other regions because the difference between the maximum and minimum values of the index is smaller than in other regions.

However, in general, the values of the Smart Development Index in districts of Latgale region are relatively low. The calculations of the median values manifest that in half of the districts of Latgale region the Smart Development Index is less than 0.43, and this value is about 2.5 times lower than the index mean value of 1.074 . The median value in Latgale region testifies to the fact that in most of the region's rural areas, smart development is markedly delayed in comparison with other regions of Latvia. For example, the highest median value of 4.03 is observed in Vidzeme region and this indicator is nine times higher than in the region of Latgale. Furthermore, in Vidzeme region the difference between the median and the average values of the index is very small.

In general, the statistical data of the values of the Smart Development Index show that although Latgale region is lagging behind the other regions as to the level of smart development, smart development in the region proceeds more evenly.

The Smart Development Index in Latgale region reflects the division of districts into two similar groups where the first group consists of 10 districts with positive index values and the second group comprises nine districts with negative index values.

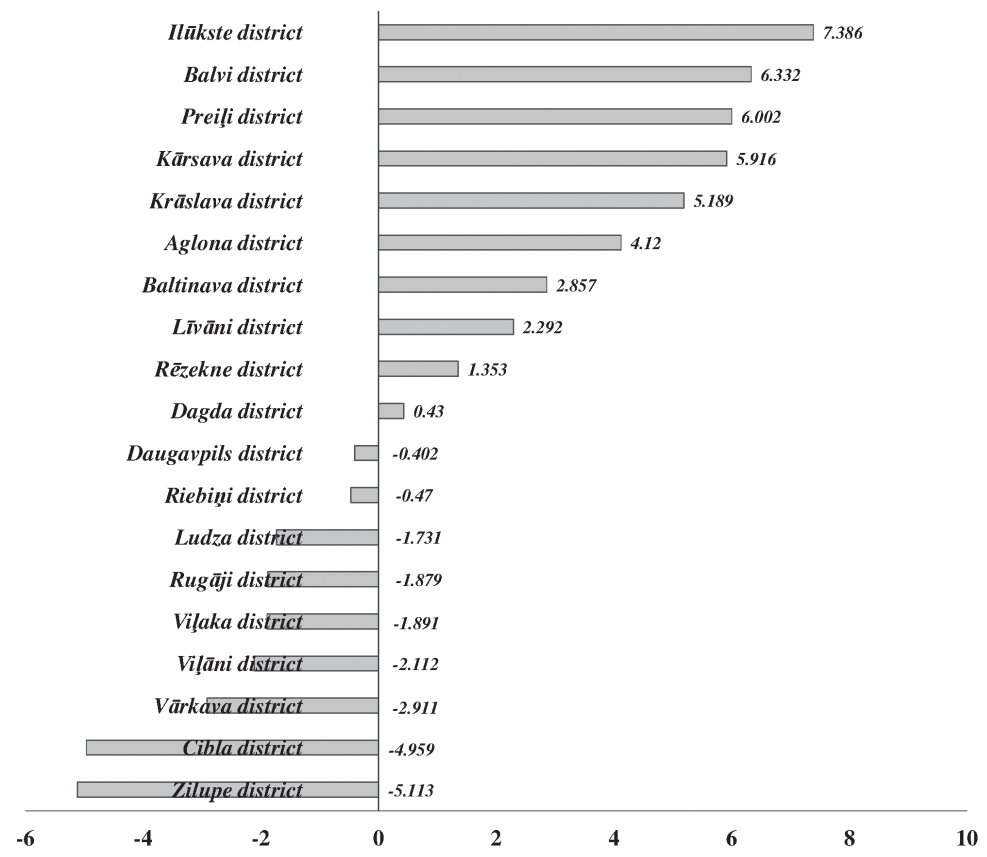

Figure 2. Smart Development Index in Latgale districts

Source: EKOSOC-LV data. 
Taking into account the data of RDIM (2015), it is possible to calculate that in the group of districts with positive index values, in 2014 there lived $62.31 \%$ of Latgale region's residents, which is a trend favouring smart development. However, as to the group of districts with the positive values of the Smart Development Index, the rate of development observed is low or below the average in all 10 districts. The districts, in which the development rate is above average or high (Daugavpils, Vārkava, Cibla and Zilupe), are located in the group of districts showing negative values of the Smart Development Index.

As a result of the calculations made, the analysis of the obtained data allows pointing out that smart development observed in Latgale region proceeds rather evenly in different districts; however, the districts with a higher level of smart development develop slower than the districts with a lower level of smart development. The variety of the identified trends in smart development in the context of Latgale region triggers the wish to understand the causes, which is possible by analysing the data on the dimensions of the index, that are, Resources, Population, Economy and Management.

Table 4

Correlation between the Smart Development Index and Its Dimensions

\begin{tabular}{lcccc}
\hline Regions & Resources & Population & Economy & Management \\
\hline $\begin{array}{l}\text { Latgale } \\
(\mathrm{n}=19)\end{array}$ & 0.548 & 0.615 & 0.218 & 0.419 \\
\hline $\begin{array}{l}\text { Kurzeme } \\
(\mathrm{n}=18)\end{array}$ & 0.363 & 0.584 & 0.610 & 0.409 \\
\hline $\begin{array}{l}\text { Pierīga } \\
(\mathrm{n}=28)\end{array}$ & 0.018 & 0.804 & 0.732 & 0.471 \\
\hline $\begin{array}{l}\text { Vidzeme } \\
(\mathrm{n}=25)\end{array}$ & 0.411 & 0.589 & 0.391 & 0.729 \\
\hline $\begin{array}{l}\text { Zemgale } \\
(\mathrm{n}=20)\end{array}$ & 0.369 & 0.717 & 0.797 & 0.303 \\
\hline
\end{tabular}

Note: $\mathrm{n}$ - number of districts in region.

Source: developed by the authors, EKOSOC-LV data.

The values of the correlation coefficient between the Smart Development Index and its dimensions manifest that smart development in Latvian regions has different focuses. Relatively close and strong correlations are observed between the Smart Development Index and such its dimensions as Population, Economy and Management, while the correlation between the dimension Resources and smart development is generally weak.

Thus, in the regions of Kurzeme and Zemgale, the highest value of the correlation coefficient has been observed between the Smart Development Index and the dimension Economy, $r=0.610$ and $r=0.797$, respectively. Vidzeme region shows a stronger link between the Smart Development Index and Management $(r=0.729)$, while in the region of Pierīga, smart development is stronger correlated with Population $(r=0.804)$.

Similarly, in Latgale region, a closer relationship has been observed between the Smart Development Index and the dimension Population $(r=0.615)$, but the relationship with other dimensions of smart development in Latgale region differs from other regions. It is worth paying attention to the fact that in Latgale region the value of the correlation 
coefficient is extremely low between the Smart Development Index and the dimension Economy $(r=0.218)$, which features the correlation that is several times weaker than in other regions. By contrast, the correlation between the Smart Development Index and the dimension Resources in Latgale region is medium close and higher than in other regions. The data on the correlation between the Smart Development Index and the dimensions Population and Management in Latgale region are similar to those in other regions.

To some extent, the values of the correlation coefficient between the Smart Development Index and its dimensions account for the level of the overall development of Latgale region. As indicated by the experts (e.g., Latgales plānošanas regions, 2010a, 2010b), in Latgale region one can observe the decline in social capital and the use of natural resources, resulting in low added value, which is not particularly favourable taking into consideration that the dimensions Population and Resources prevail in the region's smart development. At the same time, it indicates the spheres for active work towards the improvement of the situation.

Table 5

Prevailing Dimensions of the Smart Development Index in the Districts of Latgale Region (in accordance with the values of the dimensions)

\begin{tabular}{|c|c|c|c|}
\hline & Districts of Latgale region & $\begin{array}{l}\text { Position according to the values } \\
\text { of Smart Development Index }\end{array}$ & Prevailing dimension \\
\hline \multirow{10}{*}{ 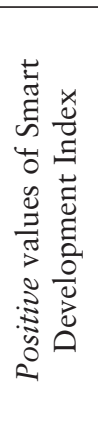 } & Ilūkste district & 1 & Management \\
\hline & Balvi district & 2 & Economy \\
\hline & Preiḷi district & 3 & Population \\
\hline & Kārsava district & 4 & Management \\
\hline & Krāslava district & 5 & Management \\
\hline & Aglona district & 6 & Resources \\
\hline & Baltinava district & 7 & Management \\
\hline & Līvāni district & 8 & Economy \\
\hline & Rēzekne district & 9 & Resources \\
\hline & Dagda district & 10 & Economy \\
\hline \multirow{9}{*}{ 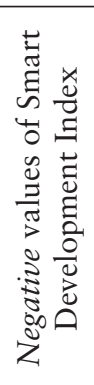 } & Daugavpils district & 11 & Population \\
\hline & Riebiņi district & 12 & Management \\
\hline & Ludza district & 13 & Population \\
\hline & Rugāji district & 14 & Management \\
\hline & Vilaka district & 15 & Management \\
\hline & Viḷāni district & 16 & Management \\
\hline & Vārkava district & 17 & Management \\
\hline & Cibla district & 18 & Resources \\
\hline & Zilupe district & 19 & Economy \\
\hline
\end{tabular}

Source: developed by the authors, EKOSOC-LV data.

According to the values of four dimensions of the Smart Development Index in the districts of Latgale region, it is possible to identify the dominant dimension in the index structure of each district. The common trend demonstrates a strong dominance of the dimension Management in both the group of the districts with positive values of Smart Development Index and the group of districts with negative ones. Thus, the indicator of 
Management shows higher values in nine districts, but mostly in the group (five districts) with negative index values. However, Management is the dominant dimension in the Smart Development Index in Ilūkste district, which ranks first in the region of Latgale as to smart development (see Figure 2).

Given that the correlation between the Smart Development Index and Management in the region of Latgale is weak $(r=0.419)$ and lags behind the correlations featured by the dimensions of Population and Resources, it is possible to conclude that the performance of nine districts in the dimension Management is not sufficiently reflected in smart development of Latgale region and it is necessary to take measures in order to improve the situation.

The dimension Economy dominates in the Smart Development Index in four districts and three of them belong to the group with positive index values. In addition, the dimension Economy dominates in Balvi district, which occupies the second place as to smart development in Latgale region. All in all, in the region of Latgale, the link between smart development and the dimension Economy is weak $(r=0.218)$, which is partially explained by the fact that business activity there is relatively low (e.g., Latgales plānošanas regions, 2010a, 2010b).

The dimension Population in the Smart Development Index is the dominating one in three districts, mostly in the group of districts with negative index values. However, Preili district, which ranks third in Latgale region, demonstrates the dominance of the smart development dimension Population. Given that in the region of Latgale, smart development demonstrates a closer correlation with the dimension Population, but it is rarely the dominant one in districts and in most of the ascertained cases dominates in the regions with negative values of Smart Development Index one cannot but agree with the conclusion that in Latgale region a negative trend is being observed, i.e., the decrease of social capital because of the decline in the number of people (e.g., Latgales plānošanas regions, 2010a, 2010b). This causes a situation that such an important constituent of smart development as Population in districts often is sufficient neither in quantity nor in quality (see the features of the description of rural areas, for instance, Steiner, Mossbock, 2014).

The dimension Resources as a dominant dimension in the structure of Smart Development Index is also found in three districts and mainly in the ones with positive index values, e.g., Aglona district and Rēzekne district, which respectively occupy the sixth and the ninth places as to smart development. Taking into consideration that in Latgale region the correlation between the Smart Development Index and the dimension Resources has been identified as medium close with a higher correlation coefficient than in other regions, but the efficiency of the use of resources might be better (e.g., Latgales plānošanas regions, 2010a, 2010b), it is possible to assume that this area in Latgale region has a huge potential for the promotion of smart development in rural areas.

In general, the quantitative assessment of smart development has shown that smart development in Latgale region proceeds differently in different districts. The complex analysis of the data collected allows emphasising that during the period of 2009-2014 smart development of Latgale region was mainly promoted by the rural areas that showed good performance in the dimensions Population and Resources. 


\section{The Qualitative Assessment of Smart Development: Triple-Helix Representatives' Opinions}

One of the key aspects in the application of the concept of smart specialisation is the involvement of all parties (e.g., Krueger, 2010) and lively discussions, as well as explaining the nature of the concept (e.g., Poliakaite et al., 2015). In April 2016, within the framework of the National Research Programme EKOSOC-LV, a scientific and practical seminar "Possibilities of Smart Development in Latvian Rural Areas and Regions" was organized, in which a particular attention was paid to the region of Latgale. During the seminar, a survey of experts representing the public sector, entrepreneurship and research was organized; the survey was carried out by means of the AHP method. The main results of the survey are presented in this section of the paper and help understand the analysis of the quantitative results. The experts were asked about four dimensions of smart development and their importance in the development of Latgale region, as well as about the influence of the population, the municipalities, the state and the EU, thus determining the prevailing impact factors, i.e., the population's initiative and activity or the institutional environment.

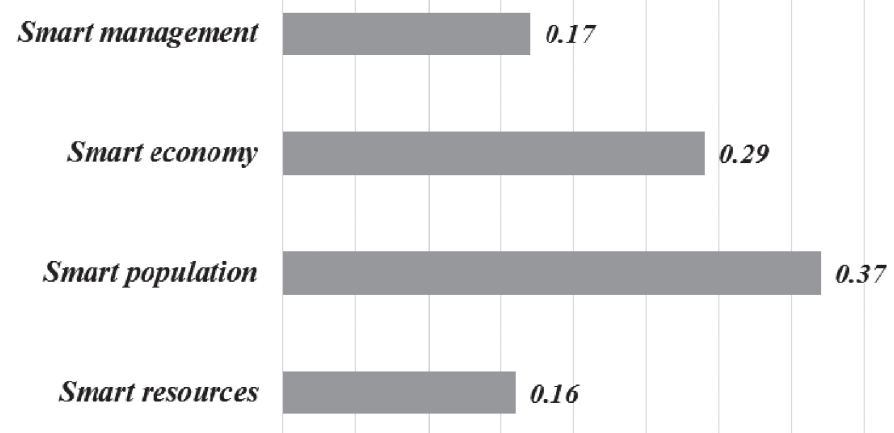

Figure 3. The importance of the dimensions of the Smart Development Index in smart development of Latgale region according to the experts' opinions

Source: developed by the authors, EKOSOC-LV data.

According to the experts, the major role in ensuring smart development belongs to the dimensions Population (0.37) and Economy (0.29). The dimensions Management (0.17) and Resources (0.16), according to the experts, are less important in the process of smart development. The combination of the quantitatively determined trends of smart development in Latgale region and the experts' evaluation (the qualitative assessment) of the significance of the dimensions of the Smart Development Index in smart development of Latgale region allows for the description of the determined trends of smart development.

The most obvious trend of smart development in Latgale region is attributable to the fact that the dimensions Resources and Economy are found among the prevailing dimensions neither in the quantitative nor the qualitative assessment. This might be explained by the widely known negative trends in Latgale region related to Resources and Economy, which are also reflected in the experts' viewpoints. These negative trends are the low business activity (applicable to the dimension Economy) and the use of 
natural resources to develop low value added (applicable to the dimension Resources) (e.g., Latgales plānošanas regions, 2010a, 2010b).

Table 6

The Prevailing Dimensions in Latgale Region's Smart Development according to the Results of the Quantitative and Qualitative Assessments

\begin{tabular}{|c|c|c|c|c|}
\hline Dimensions of Smart Development Index & 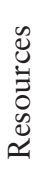 & 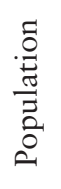 & $\begin{array}{l}\vec{\Xi} \\
0 \\
0 \\
0 \\
\text { I } \\
\text { I }\end{array}$ & 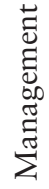 \\
\hline $\begin{array}{l}\text { The dimension has the closest correlation with the Smart Development } \\
\text { Index in Latgale region }\end{array}$ & & $X$ & & \\
\hline $\begin{array}{l}\text { The dimension has a dominant position in the group of districts with } \\
\text { positive values of the Smart Development Index }\end{array}$ & & & & $\mathrm{X}$ \\
\hline $\begin{array}{l}\text { The dimension has a dominant position in the group of districts with } \\
\text { negative values of the Smart Development Index }\end{array}$ & & & & $\mathrm{X}$ \\
\hline $\begin{array}{l}\text { The dimension is of greater significance, according to the state, } \\
\text { entrepreneurship and research experts' viewpoints }\end{array}$ & & $X$ & & \\
\hline
\end{tabular}

Source: developed by the authors, EKOSOC-LV data.

Being aware of the regions' commitments to move towards the proportion of knowledge-based development, it is clear that the dimension Population takes a leading role, however, taking into account that the level of economic development in Latgale region is lagging behind the average national indicators, more attention should be devoted to the dimensions Economy and Resources, as well as the performance of Management in different districts should be counterbalanced.

Taking into account the numerical values of the features analysed (see Tables 1, 2, $3,4,5)$, it is possible to provide a detailed description of the features of smart development in Latgale region. Thus, the results of the analysis reveal that the dimension Resources has closer correlation with smart development of Latgale region than the dimension Economy, while Economy has a greater role than Resources according to the experts' opinions. The dimension Management demonstrates dominance in the districts' smart development more frequently than the other dimensions irrespectively of the districts' "success" in the sphere of smart development. It appears that the "point of compromise" is the dimension "Population", which, according to the calculation of the correlation coefficient made, has medium strong correlation (and a higher correlation coefficient than the other dimensions $r=0.615$ ) with the Smart Development Index and expressed greater importance for smart development according to the experts' views (0.37). The results might indicate a vivid reaction to the decrease in the number of people of Latgale region at the time when the new paradigm of regional development emphasises exactly the importance of human capital.

Following the results of the survey, we have also summarised the views on practical implementation of the concept of smart specialization, determining what - populations' initiative and activity or institutional environment - affects a region's progress towards sustainability in the development most of all. 
Table 7

The Factors Affecting Smart Specialization of Latgale Region according to the Experts' Opinions

\begin{tabular}{|c|c|c|c|}
\hline $\begin{array}{l}\text { Population's } \\
\text { influence } \\
0.15\end{array}$ & $\begin{array}{c}\text { Influence of } \\
\text { municipalities } \\
0.19\end{array}$ & $\begin{array}{c}\text { Influence of } \\
\text { the state } \\
0.34\end{array}$ & $\begin{array}{c}\text { The European Union } \\
\text { (EU) influence } \\
0.31\end{array}$ \\
\hline $\begin{array}{l}0.12 \text { - Development } \\
\text { and implementation } \\
\text { of innovative ideas }\end{array}$ & $\begin{array}{l}0.10 \text { - Attraction } \\
\text { and use of the EU } \\
\text { structural funds }\end{array}$ & $\begin{array}{l}0.10 \text { - Sustainable } \\
\text { economic environ- } \\
\text { ment }\end{array}$ & $\begin{array}{l}0.22 \text { - Implementation } \\
\text { of the EU Cohesion } \\
\text { Policy }\end{array}$ \\
\hline $\begin{array}{l}0.15 \text { - Involvement } \\
\text { in formal and non- } \\
\text { formal education }\end{array}$ & $\begin{array}{l}0.17 \text { - Employees' } \\
\text { competence }\end{array}$ & $\begin{array}{l}0.16 \text { - Support for } \\
\text { innovative } \\
\text { businesses }\end{array}$ & $\begin{array}{l}0.17 \text { - Cooperation } \\
\text { among the EU Member } \\
\text { States in promoting } \\
\text { innovative processes }\end{array}$ \\
\hline $\begin{array}{l}0.38 \text { - Readiness and } \\
\text { capacity to become } \\
\text { an entrepreneur }\end{array}$ & $\begin{array}{l}0.37 \text { - Cooperation } \\
\text { with population, } \\
\text { entrepreneurs }\end{array}$ & $\begin{array}{l}0.35 \text { - Ensuring the } \\
\text { EU funding for the } \\
\text { promotion of smart } \\
\text { specialisation in regions }\end{array}$ & $\begin{array}{l}0.29 \text { - The EU strategy } \\
\text { for the promotion of } \\
\text { innovative activity }\end{array}$ \\
\hline $\begin{array}{l}0.35 \text { - The use of } \\
\text { available resources } \\
\text { for increasing pros- } \\
\text { perity }\end{array}$ & $\begin{array}{l}0.36-\text { Efficient use } \\
\text { of resources }\end{array}$ & $\begin{array}{l}0.39-\text { Equalisation of } \\
\text { financial resources and } \\
\text { successful implement- } \\
\text { ation of tax policy }\end{array}$ & $\begin{array}{l}0.32-\text { The EU policy } \\
\text { guidelines for the prom- } \\
\text { otion of regional spec- } \\
\text { ialisation and compet- } \\
\text { itiveness }\end{array}$ \\
\hline
\end{tabular}

Note: Details of questionnaire can be obtained from the authors upon request.

Source: developed by the authors, EKOSOC-LV data.

The data show that in the experts' opinion, the greatest role in smart development of Latgale region belongs to the impact of the state (0.34), the influence of the EU (0.31), followed by the influence of municipalities (0.19) and the population $(0.15)$. Such a distribution of influence indicates the population's importance in the process of smart development; the population's influence is reflected in a certain level of development depending on the circumstances, which have been ensured by the activities of the state and the EU institutions, financial instruments, and municipalities. The experts consider that there are also a number of key activities that significantly contribute to the implementation of smart specialization in the region.

Thus, according to the experts' opinions, greater involvement of the population in business activities $(0.38)$ and a more active use of available resources $(0.35)$ would increase the population's influence on and contribution to the assurance of smart specialization. The experts also point out that the involvement in formal and non-formal education $(0.15)$ and the inclination to create and implement innovative ideas $(0.15)$ also contribute to the development of smart specialisation in the region. However, the possibilities for people to exercise their influence in the areas indicated are to a certain extent dependent on the conditions created by the state, the EU and local governments.

Considering the key factors in the municipalities' influence on the region's smart specialization, the experts have acknowledged the following ones as equally essential: ability to cooperate with both inhabitants and entrepreneurs $(0.37)$ and the ability to participate in the efficient use of resources (0.36). Municipal employees' competence has been evaluated as having less impact $(0.17)$, and even lesser influence has been reported for the municipalities' abilities to attract the financial means of the EU structural funds 
(0.10). The state's influence on ensuring smart development, according to the experts' opinions, is mainly associated with the use of mechanisms of equalising financial means and successful implementation of tax policy (0.39), as well as ensuring the availability of the EU funds for the promotion of smart specialisation in the regions $(0.35)$. The influence of supporting innovative businesses $(0.16)$ and sustainable economic environment (0.19), according to the experts, is of little significance.

Finally, according to the experts' assessment, the influence of the EU on smart development in the region is related to the EU policies and guidelines for the formation of regional specialization and competitiveness (0.32), as well as to the EU strategy for the provision of innovative and competitive entrepreneurship (0.29) and the EU cohesion policy (0.22). The cooperation among the EU member states in stimulating innovative processes $(0.17)$, according to the experts, has the smallest impact on smart development.

The arrangement of the experts' assessments according to the assessment of the importance allotted to each factor makes it possible to point out that the most significant factors influencing smart development in Latgale region are:

1. the equalisation of financial resources and successful implementation of tax policy (0.39), which are manifested as the state's influence;

2. the population's readiness and capacity to become entrepreneurs $(0.8)$ - the population's influence;

3. the municipalities' ability to cooperate with the population and entrepreneurs (0.37) - influence of municipalities;

4. the involvement of municipalities in ensuring the effective use of resources (0.36) - the influence of municipalities;

5. ensuring the EU financing for the promotion of smart specialisation in the regions $(0.35)$ - the state's influence;

6. the use of available resources for prosperity (0.35) - the population's influence;

7. the EU policies in promoting regional specialisation and competitiveness (0.32) - the EU influence;

8. the EU strategy for the promotion of innovative activity $(0.29)$ - the EU influence.

The impact values taken into account, the other factors of influence essentially lag behind the eight factors with greater impact values listed above. The factors listed indicate equal representation of population, municipalities, the state and the EU in ensuring smart development. The experts have attributed high importance to two factors in each of the spheres of influence. Taking into consideration the division of the most essential impact factors according to the position of the impact indicators, it is possible to emphasise that the greatest impact is produced by the activities of the state and municipalities, followed by the population and the EU.

The qualitative assessment allows for the conclusion that Population and Economy are the cornerstones of smart specialization in Latgale region. However, the experts' opinions are, to a certain extent, affected by the negative trends existing in the region, the reduction of which is one of the most important tasks in ensuring sustainable development. All in all, the experts have acknowledged that the population's initiatives and activities play an important role in ensuring smart regional specialization, but the local institutional environment is considerably more significant. 


\section{Conclusions}

In research literature, scholars have only recently started to consider sustainability and regional development as related notions. Sustainable regional development envisages balancing environmental, social and economic needs, and in most cases environmental issues are in the focus of attention (e.g., Krueger, 2010).

The scientific works, which focus on sustainability in regional economic development, are largely based on the concept of smart specialization and the development of knowledge-based economy (e.g., Naldi et al., 2015), while in the USA smart development and sustainable development are considered as being similar (e.g., Krueger, 2010).

The European Union has set the objective to promote sustainable development, mostly by linking it to the solution of local problems and emphasising the uniqueness of each territory, comparative advantages of the territories, availability of resources, which is possible by using the strategy of smart specialization (e.g., Koumparou, 2013). It is increasingly often emphasised that sustainability is to be assessed and accessed locally, i.e., at the levels of municipalities, towns and regions (e.g., Shen et al., 2011; Sustainable Cities, Canadian International Development Agency, 2012).

At the same time, scholars also note the complexity of achieving sustainable development in pronouncedly different rural areas (e.g., Naldi et al., 2015), which is determined by the limits of experience and the lack of a unified methodological approach. However, there is a common understanding that the holistic approach is of great significance in promoting sustainable development as it includes environment, society, economy and management by using a diverse range of measurable indicators.

In Latvia, the assurance of sustainable development by using the concept of smart specialisation is being addressed in the framework of the National Research Programme EKOSOC-LV with the aim to develop an instrument by means of which it would be possible to propose scientifically grounded propositions for the assurance of balanced and sustainable rural development (Latvijas Zinātṇu Akadēmija, 2014).

During the 3rd stage of the research programme, the researchers have obtained quantitative and qualitative indicators that allow for the assessment of the process of sustainable development in the economically less developed region of Latvia, i.e., Latgale. The quantitative assessment is based on the integrated index - Smart Development Index, which combines four dimensions (Resources, Population, Economy and Management), while the qualitative assessment is based on the opinions of experts - representatives of the government, entrepreneurship and research spheres.

Taking into consideration that in $84 \%$ of the districts in Latgale region, the number of people is small, and the rate of development is low, ensuring sustainable development is both a necessity and a challenge. The quantitative assessment of sustainable development by using the concept of smart specialization has shown that there are considerable differences in the way smart development proceeds in different districts of Latgale region. 19 districts of Latgale region have been divided into two similar groups, where one group comprises 10 districts with positive values of the Smart Development Index and the other group consists of 9 districts with negative values of the Smart Development Index. The data of descriptive statistics allow showing that Latgale region, though lagging behind the other regions of Latvia, still manifests smoother advance of smart development.

The complex analysis of the quantitative indicators obtained emphasises the great significance of the dimensions Population and Resources. Contrary to the expectations, 
the contribution of the dimension Economy to smart development of Latgale region has proven to be very modest. However, it has been allotted great significance in the experts' assessment.

All in all, the qualitative assessment allows determining the dimensions Population and Economy as the cornerstones of smart specialisation of Latgale region. It should be noted that the dimension Population considerably prevails in both the quantitative and qualitative assessments. To some extent, dominance of the dimension Population over the other dimensions in Latgale region could be related to such a negative trend observed in the region as the decrease in the number of people. Assessing the impact of the dimension Population on the region's smart development, the experts have acknowledged that the population's initiatives and activities play an important role in ensuring smart specialization of the region, but the most important role belongs to the local institutional environment.

Within the framework of the National Research Programme EKOSOC-LV being at the 3rd stage of its implementation, the researchers had the opportunity to carry out the quantitative and qualitative assessment of smart development in rural areas of Latgale region. The results obtained have both scientific and practical significance in promoting sustainable development in rural areas. First, the results of the study propose a possible methodological solution to the assessment of sustainable development by using the concept of smart specialization. Second, the acquired research experience can be used for solving practical tasks at the level of districts of the region of Latgale.

\section{Acknowledgements}

The study has been supported by the National Research Programme 5.2 "Economic Transformation, Smart Growth, Governance and Legal Framework for Sustainable Development of the State and Society - A New Approach to the Creation of a Sustainable Learning Community" (EKOSOC-LV).

\section{References}

Arcelus, FJ, Arocena, P., Cabases, F., \& Pascual P. (2015). On the Cost-Efficiency of Service Delivery in Small Municipalities. Regional Studies, 49 (9), 1469-1480. http://dx.doi.org/10.1080/00343404.2013.837872

Baldi, G., \& Šipilova, V. (2014). Economic structure, welfare, and the real exchange rate. The International Journal of Interdisciplinary Social and Community Studies, $8(2), 13-22$.

Copus, A., \& Noguera, J. (2010). A Typology of Intermediate and Predominantly Rural NUTS 3 Regions. The ESPON 2013 Programme Applied Research Project 2013/ 1/2. EDORA (European Development Opportunities for Rural Areas). Version 4, 17 September 2010. Retrieved 10 August 2015, from http://www.nordregio.se/ Global/Research/EDORA/EDORA_2.22.pdf

Eiropas Savienības Padome. (2006). ES ilgtspējīgas attīstības stratēgija. Retrieved 13 April 2016, from www.varam.gov.lv/.../ilgtspejiga.../ST10917-RE03[1].LV06. DOC.doc

ESPON, University Rovira i Virgil. (2012). ATTREG - The Attractiveness of European Regions and Cities for Residents and Visitors. Retrieved 10 August 2015, from 
https://www.espon.eu/export/sites/default/Documents/Projects/AppliedResearch/ ATTREG/FR_20130123/ATTREG_FR.pdf

ESPON. (2013). Programme Applied Research Project 2013/1/2. EDORA (European Development Opportunities for Rural Areas). Version 4, 17 September 2010. Retrieved 10 August 2015, from http://www.nordregio.se/Global/Research/EDORA/ EDORA_2.22.pdf

European Commission. (2012). Connecting Smart and Sustainable Growth through Smart Specialisation. A practical guide for ERDF managing authorities. Retrieved 13 April 2016, from http://ec.europa.eu/regional_policy/sources/docgener/presenta/ green_growth/greengrowth.pdf doi:10.2776/70221

European Union. Directorate General for Regional Policy. (2011). Cities of TomorrowChallenges, Visions, Ways Forward. Retrieved 13 April 2016, from http://ec.europa. eu/regional_policy/sources/docgener/studies/pdf/citiesoftomorrow/cities of tomorrow_final.pdf doi:10.2776/41803

Gedminaite-Raudone, Z. (2014). Economic assessment of uniqueness of the regions in the context of the European Union. Procedia - Social and Behavioral Sciences, 110, 259-266. doi: https://doi.org/10.1016/j.sbspro.2013.12.869

Huggins, R., Izushi, H., Prokop, D., \& Thompson, P. (2014). Regional evolution and waves of growth: A knowledge-based perspective. Expert Systems with Applications, 41, 5573-5586. doi: http://doi.org/10.1016/j.eswa.2014.02.008

Iliško, Dz., Skrinda, A., \& Mičule, I. (2014). Envisioning the future: Bachelor's and Master's degree students' perspectives. Journal of Teacher Education for Sustainability, 16(2), 88-102. doi: https://doi.org/10.2478/jtes-2014-0013

Kirk, K., Tableporter, J., Senn, A., Day, J., Cao, J., Fan, Y., Slotterback, C.S., Goetz, E., \& McGinnis, L. (2010). Framework for Measuring Sustainable Regional Development for the Twin Cities Region. Final Report. Center for Transportation Studies University of Minnesota. Retrieved 13 April 2016, from www.cts.umn.edu/Publications/ ResearchReports/pdfdownload.pl?id=1328

Koumparou, D. (2013). The role of natural resources and the social capital in EU's growth strategy - Europe 2020. In TD Lekkas (Ed.), Proceedings of the 13th International Conference on Environmental Science and Technology. Retrieved 10 March 2017, from http://apps.webofknowledge.com/full_record.do?product=WOS\& search_mode $=$ GeneralSearch \&qid $=4 \& S I D=V 1 X g p u 7 j f u C i t d g m T Z D \&$ page $=$ $1 \& \mathrm{doc}=1$

Krueger, R. (2010). Smart growth and its discontents: An examination of American and European approaches to local and regional sustainable development. Doc. Anàl. Geogr., 56/3, 409-433.

Latgales plānošanas regions. (2010a). Latgales attīstības stratēǵija 2030. Retrieved 17 October 2016, from http://www.latgale.lv/lv/padome/planosana

Latgales plānošanas regions. (2010b). Latgales plānošanas reǵiona attīstības programma 2010-2017. Esošās situācijas analize. Retrieved 17 October 2016, from http://www.latgale.lv/lv/padome/planosana

Latvijas Zinātṇu Akadēmija. (2014). Valsts pētījumu programma 5.2.1. "Tautsaimniecības transformāciju, gudra izangsme, pārvaldība un tiesiskais ietvars valsts un sabiedrības ilgtspējīgai attīstībai - jaunas pieejas ilgtspējīgas zināšanu sabiedrības veidošanai (EKOSOC-LV)". Retrieved 13 April 2016, from http://www.lza.lv/ index.php?option=com_content\&task=view\&id=2312\&Itemid=443 
Lindqvist, M., Smed Olsen, L., \& Perjo och Haukur Claessen, L. (2013). Implementing the concept of smart specialisation in the Nordic countries. An exploratory desk study. Nordregio Working Paper, 2013:1. Retrieved 13 April 2016, from https://www.diva-portal.org/smash/get/diva2:700298/FULLTEXT01.pdf

Marsal-Llacuna, M.-L., Colomer-Llinàs, J., \& Mel ndez-Frigola, J. (2015). Lessons in urban monitoring taken from sustainable and livable cities to better address the Smart Cities initiative. Technological Forecasting and Social Change, 90(PB), 611622. doi: http://doi.org/10.1016/j.techfore.2014.01.012

Melbarde, V., \& Ore, M. (2016). Influencing factors of rural areas development: Vidzeme region case analysis. Proceedings of the New Challenges of Economic and Business Development - 2016 (pp. 484-495).

Muscio, A., Rivera León, L., \& Reid, A. (2013). Can Smart Specialisation Help Overcome the Regional Innovation Paradox. UCL-SSEES, London. Retrieved 13 April 2016, from https://www.ucl.ac.uk/ssees/docs/economics-and-business-seminarsdocuments/smart-specialisation-regional-innovation-paradox.pdf

Naldi, L., Nilsson, P., Westlund, H., \& Wixe, S. (2015). What is smart rural development? Journal of Rural Studies, 40, 90-101. doi: http://doi.org/10.1016/j.jrurstud.2015. 06.006

OECD. (2013). Innovation-driven Growth in Regions: The Role of Smart Specialisation. Preliminary Version. Retrieved 13 April 2016, from https://www.oecd.org/ innovation/inno/smart-specialisation.pdf

Ostrovska, I., Šipilova, V., Aleksejeva, L., Jermolajeva, E., \& Oḷehnovičs, D. (2016). Mūsdienu reğionālās attīstības paradigmas īpatnības: Ārvalstu zinātniskās pieredzes apkopojums. Proceedings of the International Scientific Conferences of Faculty of Social Sciences of Daugavpils University. The materials of the International Scientific Conference "Social Sciences for Regional Development 2015", 16-17 October 2015. Part I. Issues of Sociology (pp. 55-74).

Paliokaite, A., Martinaitis, Ž., \& Reimeris, R. (2015). Foresight methods for smart specialisation strategy development in Lithuania. Technological Forecasting and Social Change, 101, 185-199. doi: http://doi.org/10.1016/j.techfore.2015.04.008

Pārresoru koordinācijas centrs. (2012). Latvijas Nacionālais attīstības plāns 2014.2020. gadam. Retrieved 17 October 2016, from http:/www.varam.gov.lv/lat/pol/ ppd/ilgtsp_att/?doc $=13858$

Regional Development Indicators Module of Spatial Development Planning Information System (RDIM). (2015). Data Tables. Retrieved 10 August 2015, from http://www. raim.gov.lv

Reidsma, P., Bakker, M.M., Kanellopoulos, A., Alam, S.J., Paas, W., Kros, J., \& de Vries, W. (2015). Sustainable agricultural development in a rural area in the Netherlands? Assessing impacts of climate and socio-economic change at farm and landscape level. Agricultural Systems, 141, 160-173. doi: http://doi.org/10.1016/j.agsy.2015. 10.009

Reimeris, R. (2016). New rules, same game: The case of Lithuanian smart specialisation. European Planning Studies, 24(8), 1561-1583. doi: http://dx.doi.org/10.1080/ 09654313.2016.1179722

Romano, A., Del Vecchio, P., Secundo, G., \& Brunetti, F. (2013). A framework for policies implementing the smart specialisation strategy: The sustainable innovation ecosystem. Proceedings of the IFKAD 2013: 8th International Forum on Knowledge 
Asset Dynamics: Smart Growth: Organizations, Cities and Communities, 12-14 June 2013 (pp. 1608-1620). Zagreb, Croatia.

Salite, I. (2015). Searching for sustainability in teacher education and educational research: Experiences from the Baltic and Black Sea Circle Consortium for educational research. Discourse and Communication for Sustainable Education, 6, 2129. doi: https://doi.org/10.1515/dcse-2015-0002

Salīte, I., Drelinga, E., Iliško, Dz., Zariņa, S., \& Oḷehnoviča, E. (2016). Sustainability from the transdisciplinary perspective: An action research strategy for continuing education course development. Journal of Teacher Education for Sustainability, 18(2), 135-152. doi: https://doi.org/10.1515/jtes-2016-0020

Salite, I., Iliško, Dz., \& Micule, I. (2015). ISE action research: Reorienting teachers' dispositions towards ESD, Latvia. Leading Practice Publication: Professional Development of University Educators on Education for Sustainable Development in European Countries (pp. 105-107). UE4SD Czech Republic. ISBN: 978-8087076-22-4.

Sandu, A.-M. (2014). Coordinates of the new EU rural development policy. QualityAccess to Success, 15(1), 463-465.

Shen, L.-Y., Ochoa, J. J., Shahb, M. N., \& Zhang, X. (2011). The application of urban sustainability indicators - A comparison between various practices. Habitat International, 35, 17-29. Retrieved 13 April 2016, from http://www.sciencedirect.com/ science/article/pii/S0197397510000263 doi: http://doi.org/10.1016/j.habitatint. 2010.03.006

Sinkiene, J., Grumadaite, K., \& Liugailaite-Radzvickiene, L. (2014). Diversity of theoretical approaches to the concept of smart city. Proceedings of the 8th International Scientific Conference Business and Management 2014, 15-16 May 2014 (pp. 933940). Vilnius Gediminas Technical University, Lithuania. DOI: 10.3846/bm. 2014.112

Šipilova, V. (2014) Regional policy as indicator of readiness for structural change: The case of Latvia. Mediterranean Journal of Social Sciences, 5(13), 391-397. DOI: 10.5901/mjss.2014.v5n13p391

Šipilova, V. (2015) When regional growth does not benefit from high-tech specialization? Explaining the experience of Latvian regions. Procedia Economics and Finance, 30, 863-875. doi: https://doi.org/10.1016/S2212-5671(15)01336-2

State Regional Development Agency (SRDA). (2010). Development of Regions in Latvia 2009. Annex 4: Development Indexes of the Planning Regions and Administrative Territories Existing since July 1, 2009. Available: http://www.vraa.gov.lv/uploads/ Development_of_Regions_2009.pdf

State Regional Development Agency (SRDA). (2011). Development of Regions in Latvia 2010. Annex 2: Planning Region, Republican City and Novads Territory Development Indexes. Retrieved 10 August 2015, from http://www.vraa.gov.lv/uploads/ Development_of_Regions_in_Latvia_2010_web_ENG.pdf

State Regional Development Agency (SRDA). (2012). Development of Regions in Latvia 2011. Annex 2: Territorial Development Indices of Planning Regions, Cities and Municipalities. Retrieved 10 August 2015, from http://www.vraa.gov.lv/uploads/ regionu \%20parskats/Regionu \%20attistiba\%20Latvija\%202011\%20ENG_ Q_ia\%20kartes\%20horizontali.pdf 
Steiner, M., \& Mossbock, J. (2014). How “smart” are rural areas? A case study approach. RSA Winter Conference 2014, 27-28 November 2014, London, UK. Retrieved 20 July 2016, from http://www.regionalstudies.org/uploads/funding/conferences/ presentations/Winter_2014_Presentations_/Michael_Steiner_and_Johannes_ Mossb\%C3\%B6ck.pdf

Sustainable Cities, Canadian International Development Agency. (2012). Indicators for Sustainability: How Cities Are Monitoring and Evaluating Their Success. Retrieved 13 April 2016, from http:/www.mayorsinnovation.org/images/uploads/ pdf/2_-_International_Case_Studies.pdf

Vanthillo, T., \& Verhetsel, A. (2012). Paradigm change in regional policy: Towards smart specialisation? Lessons from Flanders (Belgium). Belgeo, 1-2 (2012), Inaugural Issue. Retrieved 13 April 2016, from https://belgeo.revues.org/pdf/7083. DOI: 10.4000/belgeo.7083

Correspondence concerning this paper should be addressed to Researcher, Dr.oec. Viktorija Šipilova, The Institute of Humanities and Social Sciences, Daugavpils University, Parades str. 1, LV-5400, Daugavpils, Latvia. Email: viktorija.sipilova@du.lv 